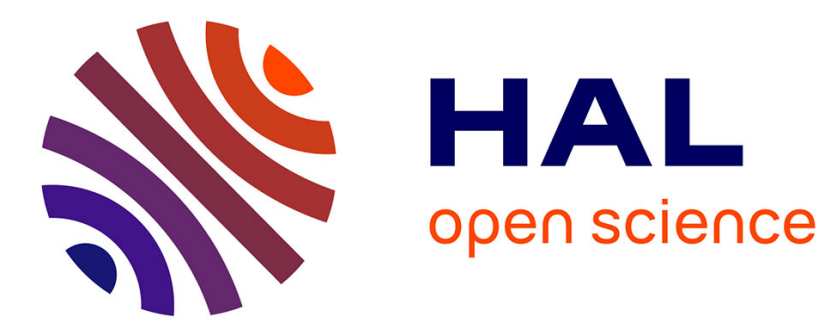

\title{
Diversification versus Specialisation: An Event Study of M\&As in the European Banking Industry
}

\author{
Laetitia Lepetit, Stéphanie Patry, Philippe Rous
}

\section{To cite this version:}

Laetitia Lepetit, Stéphanie Patry, Philippe Rous. Diversification versus Specialisation: An Event Study of M\&As in the European Banking Industry. Applied Financial Economics, 2004, 14 (9), pp.663-669. 10.1080/0960310042000233430 . hal-00804954

\section{HAL Id: hal-00804954 \\ https://hal-unilim.archives-ouvertes.fr/hal-00804954}

Submitted on 12 Nov 2014

HAL is a multi-disciplinary open access archive for the deposit and dissemination of scientific research documents, whether they are published or not. The documents may come from teaching and research institutions in France or abroad, or from public or private research centers.
L'archive ouverte pluridisciplinaire HAL, est destinée au dépôt et à la diffusion de documents scientifiques de niveau recherche, publiés ou non, émanant des établissements d'enseignement et de recherche français ou étrangers, des laboratoires publics ou privés. 


\title{
Diversification versus Specialisation: An Event Study of M\&As in the European Banking Industry
}

\author{
Laetitia LEPETIT $^{\mathrm{a}^{* *}}$, Stéphanie PATRY ${ }^{\mathrm{a}^{*}}$ \& Philippe ROUS ${ }^{\mathrm{a}^{*}}$ \\ ${ }^{a}$ Université de Limoges, LAPE, 4 place du Présidial, 87000 Limoges, France
}

March 2002

\begin{abstract}
This study examines the stock market valuation in terms of expected gains of mergers and acquisitions (M\&As) amongst banks that were announced from 1991 to 2001 in 13 European markets. We classify M\&As according to activity, geographic specialisation or diversification. A Bivariate GARCH model is used to estimate abnormal returns taking beta variability into account. Our results document that there is, on average, a positive and significant increase in value for the group of targets' banks. Moreover, we find that on average there is a positive and significant market reaction for the two types of transactions: cross-product diversification and geographic specialisation.
\end{abstract}

JEL classification : G14, G21, G34.

Keywords: European Banks Mergers and Acquisitions, Bivariate GARCH, Abnormal Returns.

Corresponding authors. Tel: +33 (0)5 554369 37; Fax: +33 (0)5 554369 31; E-mail addresses: rous@drec.unilim.fr, stephanie.patry@drec.unilim.fr, laetitia.lepetit@drec.unilim.fr

Dr Lepetit was a visitor in the Economic Department of the University of Birmingham (UK) when this article was written. 


\section{INTRODUCTION}

Over the last two decades, the European banking industry has experienced an unprecedented level of consolidation. Mergers and acquisitions (M\&As) have taken place at record levels. According to Securities Data Corporation (SDC), in the last ten years more than $1223{\mathrm{M} \& A s^{1}}$ have occurred in the European market. After averaging 15 deals a year up to 1985, European M\&As jumped to a new level of 3090 deals per year between 1991 and 2001.

To a large extent, this consolidation is based on a belief that gains can accrue through scale and scope economies, cost reduction, increased market power and reduced earning volatility. Whether or not M\&As involving banks actually achieve the expected performance gains is an important question. If consolidation causes an increase in the firm's value, then shareholder wealth can be increased. On the other hand, if M\&As do not lead to the promised positive effect, then consolidation implies a less profitable and valuable banking industry. A reading of the literature suggests that there is no clear evidence that banking mergers are economically valuable to shareholders upon announcement (Hannan and Wolken [1989], Houston and Ryngaert [1994]). This setting raises the question of whether all bank M\&As have an insignificant value effect, or whether it is possible to distinguish the types of M\&As that lead to significant gains from those that do not add value.

This study examines the impact of European M\&As announcement in terms of stock valuation. We perform an event study analysis ${ }^{2}$ of M\&As deals covering 13 European Union (EU) countries plus the Swiss market. We examine the stock market effects of M\&As in European banking between January 1991 and May 2001 by distinguishing between different types of M\&As. Specifically, M\&As are classified 
according to their specialisation or diversification along the dimensions of activity and geography ${ }^{3}$. This approach is useful to explain why the phenomena of bank M\&A's occur in light of the fact that they do not increase firm value on average. Managers wishing to engage in mergers can justify this choice by the fact that few mergers create value.

Most of the existing studies on M\&As in banking sector concern the US market. Although several studies find that the announcement of bank M\&As, on average, neither creates nor destroys stockholder value (Hannan and Wolken [1989], Pilloff and Santomero [1998]), some studies find the announcement of certain types of bank M\&As do create value. DeLong ([2001a], [2001b]) finds that M\&As focusing along geographic and activity lines create value upon announcement. Concerning the European banking market, the recent work of Cybo-Ottone and Murgia [2000] is the only study that examines the market valuation of M\&As. They analyze 54 M\&As of European financial services (not just banks) taking place between 1988 and 1995 in 13 European banking markets. They find that, on average, there is a positive and significant increase in value for the average M\&As at the time of the deal's announcement. Moreover, they uncover that there is a positive and significant market reaction for the M\&As between banks and insurance, for domestic transactions.

Our paper differs from that of Cybo-Ottone and Murgia on three main points. Firstly, whereas these authors used data from AMDATA database of Acquisitions Monthly, which has been discontinued, the statistical data required for our issue have been drawn from SDC M\&As database. SDC provides a somewhat more complete coverage than AMDATA, particularly with respect to national operations and transactions in the financial sector ${ }^{4}$. Secondly, we analyse M\&As that were 
announced on European markets from January 1991 to May 2001 and our sample construction is different. Thirdly, we model abnormal returns according to the Bivariate GARCH process to control for time-varying beta volatility instead of using the market model, which assumes constant beta. Although the use of the market model to estimate the abnormal return has a long standing, a growing body of evidence exists which suggests that both individual stock and portfolio betas are conditional in that beta varies over time (see Fabozzi and Francis [1978], Bos and Newbold [1984]). Explicitly modelling time varying betas avoids the problem of fallacious abnormal returns induced by a misspecification of beta's characteristics.

The paper is organized as follows. Section 2 presents the sample design and the data sources on European bank M\&As. Section 3 explains how abnormal returns are constructed using the Bivariate GARCH scheme and presents the results. Section 4 shows the probit analysis of deal type and abnormal returns. Section 5 concludes.

\section{SAMPLE DESIGN AND DATA SOURCES ON EUROPEAN BANK M\&As}

The primary data employed in this paper are daily stock returns of European banks involved in M\&As during the sample period from January 1991 through May 2001. The daily stock returns are obtained from Datastream International and the list of M\&As announcements from Thomson Financial Securities Data Company database (SDC-M\&A). In our paper, the terms merger and acquisition are used interchangeably to refer to transactions involving the combination of two independent firms to form one or more commonly controlled entities. The distinction between a merger and an acquisition is somewhat vague ${ }^{5}$. A merger is often defined as a transaction where one entity is combined with another so that at least one initial entity loses its distinct identity. An acquisition is often considered as a transaction 
where one firm purchases a controlling stake of another firm without combining the assets of the firms involved. In our analysis, we include transactions with majority interests in order to account for operations that have created a change in capital control. Moreover, only completed operations are considered.

The M\&As are classified according to their specialisation or diversification along the dimensions of geography and activity ${ }^{6}$. According to our approach, four consolidation scenarios can be obtained for each type of operations: (1) operations with specialised activity (SPEC) and geographic focusing (GEOF), noted SPEC\&GEOF; (2) operations with activity diversification (DIV) and with geographic focusing noted DIV\& $\mathrm{GEOF}^{7}$; (3) operations with specialisation and with geographic European diversification (GEOD) noted SPEC\& GEOD; (4) operations with crossproducts diversification and geographic diversification noted DIV\& GEOD. Table 1 presents the sample composition for the 13 European countries considered in our analysis. A majority of M\&As occurred in France, Germany, Italy, Switzerland and in United Kingdom. Cross-border M\&As (GEOD) are relatively limited and the number of domestic transactions with cross-product diversification is approximately the same as those with specialisation.

\section{ESTIMATING ABNORMAL RETURNS}

\section{Event study methodology}

We use event study methodology to estimate abnormal stock market returns. Traditionally, the standard market model is used to calculate an abnormal return (AR) for firm i on day D. This methodology suffers from the drawback of assuming a constant beta over the estimation period. The consequence may be to reject the null hypothesis (no abnormal returns) too often due to unspecified beta variability. Here, 
we employ a methodology developed by Frame \& Lastrapes [1998], using a Bivariate GARCH that allows for some beta movements,

$$
\begin{aligned}
& \mathrm{r}_{\mathrm{it}}=\mathrm{a}_{\mathrm{i} 1}+\mathrm{a}_{\mathrm{i} 2} \mathrm{r}_{\mathrm{it}-1}+\mathrm{u}_{\mathrm{it}} \\
& \mathrm{r}_{\mathrm{m} \mathrm{t}}=\mathrm{a}_{\mathrm{m} 1}+\mathrm{a}_{\mathrm{m} 2} \mathrm{r}_{\mathrm{m} \mathrm{t}-1}+\mathrm{u}_{\mathrm{mt}} \\
& \mathrm{h}_{\mathrm{iit}}=\mathrm{c}_{\mathrm{i} 1}+\mathrm{c}_{\mathrm{i} 2} \mathrm{u}_{\mathrm{it}-1}{ }^{2}+\mathrm{c}_{\mathrm{i} 3} \mathrm{~h}_{\mathrm{it}-1} \\
& \mathrm{~h}_{\mathrm{mmt}}=\mathrm{c}_{\mathrm{m} 1}+\mathrm{c}_{\mathrm{m} 2} \mathrm{u}_{\mathrm{m} t-1}{ }^{2}+\mathrm{c}_{\mathrm{m} 3} \mathrm{~h}_{\mathrm{mt}-1} \\
& \mathrm{~h}_{\mathrm{imt}}=\mathrm{c}_{\mathrm{im}} \sqrt{\mathrm{h}_{\mathrm{iit}} \cdot \mathrm{h}_{\mathrm{mmt}}}
\end{aligned}
$$

where $r_{i t}$ and $r_{m t}$ are the expected returns on security $i$ and market benchmark (Datastream General Market Index). Equations (1) and (2) define the average returns on security i and market index. Equations (3) and (4) define the conditional variances of $r_{i t}$ and $r_{m t}$. Equation (5) defines the conditional covariance. The optimised log likelihood function is:

$$
\log L_{t}=-0.5 \log \left|H_{t}\right|-0.5 u^{\prime}{ }_{t} H_{t}^{-1} u_{t}
$$

where $\left|H_{t}\right|$ is the determinant of the matrix $H_{t}$ with $H_{t}=\left[\begin{array}{ll}h_{i i t} & h_{i m t} \\ h_{i m t} & h_{m m t}\end{array}\right]$, and $\mathrm{u}_{\mathrm{t}}=\left[\mathrm{u}_{\mathrm{it}}, \mathrm{u}_{\mathrm{mt}}\right]$.

Equilibrium return $\mathrm{r}_{\mathrm{i}+\mathrm{k}}{ }^{*}$ of asset $\mathrm{i}$ at time $\mathrm{T}+\mathrm{k}$ of the event window is defined as a function of: (i) the anticipation at time $\mathrm{T}$ of beta coefficient, denoted $\beta_{\mathrm{i}+\mathrm{k}}$; (ii) the observed return on the market at time $\mathrm{T}+\mathrm{k}, \mathrm{r}_{\mathrm{m} T+\mathrm{k}}$ :

$$
\mathrm{r}_{\mathrm{i}+\mathrm{k}}^{*}=\mathrm{E}\left(\mathrm{r}_{\mathrm{i}+\mathrm{k}} \mid \mathrm{I}_{\mathrm{T}}, \mathrm{r}_{\mathrm{m} \mathrm{T}+\mathrm{k}}\right)=\mathrm{E}\left(\mathrm{r}_{\mathrm{i} \mathrm{T}+\mathrm{k}} \mid \mathrm{I}_{\mathrm{T}}\right)+\frac{\mathrm{E}\left(\mathrm{h}_{\mathrm{imT}+\mathrm{k}} \mid \mathrm{I}_{\mathrm{T}}\right)}{\mathrm{E}\left(\mathrm{h}_{\mathrm{mmT}+\mathrm{k}} \mid \mathrm{I}_{\mathrm{T}}\right)}\left(\mathrm{r}_{\mathrm{m} \mathrm{T}+\mathrm{k}}-\mathrm{E}\left(\mathrm{r}_{\mathrm{m} \mathrm{T}+\mathrm{k}} \mid \mathrm{I}_{\mathrm{T}}\right)\right)
$$

where $\mathrm{I}_{\mathrm{T}}$ is the information available at time $\mathrm{T}$ and $\frac{\mathrm{E}\left(\mathrm{h}_{\mathrm{imT}+\mathrm{k}} \mid \mathrm{I}_{\mathrm{T}}\right)}{\mathrm{E}\left(\mathrm{h}_{\mathrm{mmT}+\mathrm{k}} \mid \mathrm{I}_{\mathrm{T}}\right)}$ is expectation about $\beta_{\mathrm{i}+\mathrm{k}}$ at time $\mathrm{T}$. 
Abnormal return at time $\mathrm{T}+\mathrm{k}$ is defined as the difference between the observed return and the equilibrium return:

$$
\mathrm{AR}_{\mathrm{i} \mathrm{T}+\mathrm{k}}=\mathrm{r}_{\mathrm{i}+\mathrm{k}}-\mathrm{r}_{\mathrm{i}+\mathrm{k}}{ }^{*}
$$

and cumulated abnormal returns $(\mathrm{CAR})$ on the event window $[\mathrm{T}+1, \mathrm{~T}+\mathrm{k}]$ is:

$$
\mathrm{CAR}_{\mathrm{iT}+\mathrm{k}}=\sum_{\mathrm{j}=1}^{\mathrm{k}} \mathrm{AR}_{\mathrm{iT}+\mathrm{j}}
$$

For each security, the model (1) to (5) is estimated on a 300 days pre-event window. Then, cumulative abnormal returns are evaluated over different windows around the event Day $\mathrm{D}^{8}$ : (i) 4 one-tailed ex ante windows: [D - J, D - 1], for $\mathrm{J}=7$, 15, 30 and 60 (windows w1 to w4); (ii) 4 one-tailed ex post windows: [D, D + J], for $\mathrm{J}=7,15,30$ and 60 (windows w5 to $w 8$ ); (iii) 4 two-tailed symmetric windows: $[\mathrm{D}-\mathrm{J}, \mathrm{D}+\mathrm{J}]$, for $\mathrm{J}=7,15,30$ and 60 (windows $w 9$ to $w 12$ ).

Firstly, cumulated abnormal returns are evaluated for each of these event windows and for each bank $\mathrm{i}$. The null that there is no cumulative abnormal returns for the bank $\mathrm{i}$ over the entire event window $\left(\mathrm{CAR}_{\mathrm{i}+\mathrm{k}}=0\right)$ is tested alternatively with a parametric and a non-parametric test. The parametric statistic is the standardised cumulated abnormal return for the bank $\mathrm{i}$ on the event window [T+1, $\mathrm{T}+\mathrm{k}]$ :

$$
\mathrm{TP}_{1 \mathrm{i}}=\frac{\mathrm{CAR}_{\mathrm{iT}+\mathrm{k}}}{\sqrt{\operatorname{Var}\left(\mathrm{CAR}_{\mathrm{i}+\mathrm{k}} \mid \mathrm{I}_{\mathrm{T}},\left\{\mathrm{r}_{\mathrm{m}}\right\}\right)}},
$$

where $\operatorname{Var}\left(\mathrm{CAR}_{\mathrm{i}+\mathrm{k}} \mid \mathrm{I}_{\mathrm{T}}\right)$ is such that:

$$
\begin{aligned}
& \operatorname{Var}\left(C A_{\mathrm{iT}+\mathrm{k}} \mid \mathrm{I}_{\mathrm{T}}\right)=\lambda_{1}{ }^{2} \mathrm{~h}_{\mathrm{ii}+1}+\lambda_{2}{ }^{2} \mathrm{E}_{\mathrm{T}} \mathrm{h}_{\mathrm{iiT}+2}+\ldots+\lambda_{\mathrm{k}}{ }^{2} \mathrm{E}_{\mathrm{T}} \mathrm{h}_{\mathrm{ii}+\mathrm{k}}+ \\
& +\mu_{1}{ }^{2} \mathrm{~h}_{\mathrm{mm} \mathrm{T}+1}+\mu_{2}{ }^{2} \mathrm{E}_{\mathrm{T}} \mathrm{h}_{\mathrm{mm} \mathrm{T}+2}+\ldots+\mu_{\mathrm{k}}{ }^{2} \mathrm{E}_{\mathrm{T}} \mathrm{h}_{\mathrm{mm} \mathrm{T}+\mathrm{k}} \\
& \quad-2\left(\lambda_{1} \mu_{1} \mathrm{~h}_{\mathrm{im} \mathrm{T}+1}+\lambda_{2} \mu_{2} \mathrm{E}_{\mathrm{T}} \mathrm{h}_{\mathrm{im} \mathrm{T}+2}+\ldots+\lambda_{\mathrm{k}} \mu_{\mathrm{k}} \mathrm{E}_{\mathrm{T}} \mathrm{h}_{\mathrm{im} \mathrm{T}+\mathrm{k}}\right)
\end{aligned}
$$


with :

$\lambda_{\mathrm{k}}=1$

$\lambda_{\mathrm{k}-\mathrm{s}}=\lambda_{\mathrm{k}-\mathrm{s}+1}+\mathrm{a}_{\mathrm{i} 2}{ }^{\mathrm{s}}$

$\mu_{\mathrm{k}}=\mathrm{E}\left(\beta_{\mathrm{i}+\mathrm{k}} \mid \mathrm{I}_{\mathrm{T}}\right)$

$\mu_{\mathrm{k}-\mathrm{s}}=\mathrm{a}_{\mathrm{m} 2} \mu_{\mathrm{k}-\mathrm{s}+1}+\mathrm{E}\left(\beta_{\mathrm{i} \mathrm{T}+\mathrm{k}-\mathrm{s}} \mid \mathrm{I}_{\mathrm{T}}\right)$

$\mathrm{E}\left(\beta_{\mathrm{i} T+\mathrm{k}} \mid \mathrm{I}_{\mathrm{T}}\right)=\frac{\operatorname{Cov}_{\mathrm{T}}\left(\mathrm{r}_{\mathrm{iT}+\mathrm{k}}, \mathrm{r}_{\mathrm{mT}+\mathrm{k}}\right)}{\operatorname{Var}_{\mathrm{T}} \mathrm{r}_{\mathrm{mT}+\mathrm{k}}}$

Under the null (no abnormal returns), $\mathrm{TP}_{1 \mathrm{i}}$ is asymptotically distributed as a standard normal variable. To carry out a non-parametric test, excess returns $\mathrm{AR}_{\mathrm{it}}$ for each bank $\mathrm{i}$ are ranked on the whole (estimation + event) window. Let $\mathrm{rk}_{\mathrm{it}}$ be the centred rank of $\mathrm{AR}_{\mathrm{it}}$ among the different abnormal returns of bank $\mathrm{i}$ over this whole window. The $\mathrm{rk}_{\mathrm{it}}$ are then cumulated on the sole M days of the chosen event window. The non-parametric statistic test is:

$$
\operatorname{TNP}_{1 i}(M, U)=\frac{\frac{1}{M} \sum_{j=1}^{M} r k_{i U-j+1}}{\sqrt{\frac{1}{T-M+1} \sum_{t=J}^{T}\left(\frac{1}{M} \sum_{j=1}^{J} r k_{i t-j+1}\right)^{2}}}
$$

where $\mathrm{U}$ is the upper bound of event window ${ }^{9}$ and $\mathrm{T}$ is the upper bound of the $[1, \mathrm{~T}]$ estimation window. The right hand side denominator is the standard deviation of the cumulated and standardised ranks as evaluated on estimation windows. Under the null, $\mathrm{TNP}_{1 \mathrm{i}}$ would be standard normal.

Secondly, we test the null that there is no abnormal return for the entire bank sample and over the entire event window. 
The statistic used is:

$$
\mathrm{T}_{2}=\frac{\overline{\mathrm{SCAR}}}{\mathrm{s}_{\overline{\mathrm{SCAR}}}}=\frac{\frac{1}{\mathrm{~N}} \sum_{\mathrm{i}=1}^{\mathrm{N}} \operatorname{SCAR}_{\mathrm{i}}}{\sqrt{\frac{1}{\mathrm{~N}(\mathrm{~N}-1)} \sum_{\mathrm{i}=1}^{\mathrm{N}}\left(\operatorname{SCAR}_{\mathrm{i} U}-\overline{\mathrm{SCAR}}\right)^{2}}}
$$

where $\mathrm{N}$ is the number of banks in the sample, $\mathrm{SCAR}_{\mathrm{iU}}$ is the standardised cumulative abnormal return for bank $\mathrm{i}$ at the upper bound $\mathrm{U}$ of the event window and $\overline{\mathrm{SCAR}}$ is the cross section mean of the different $\mathrm{SCAR}_{\mathrm{iU}}$. Under the null $\mathrm{T}_{2}$ is asymptotically distributed as a standard normal variable.

Results

Whole results are not reported here. Table 2 resumes $T_{2}$ values using various windows and sampling M\&As' according to: (i) the status of the entity, target or bidder; (ii) the geographic dimension, with a same or a different geographic area for the two entities; (iii) the activity dimension, with a cross-product diversification or a specialisation. These statistics are presented for both event windows $[-7,+7]$ and $[-15,+15]^{10}$. According to $\mathrm{T}_{2}$ statistic values, cumulative abnormal returns are positive and significant for the whole sample. Thus, as a whole, European M\&As in banking industry lead to significant increase in overall value. This result is not consistent with the findings of most event studies carried out for the U.S. banking market. Although, $\mathrm{TP}_{1}$ and $\mathrm{TNP}_{1}$ statistics show that less than $10 \%$ of the deals present, individually, a significant abnormal return. Thus the market expects a value effect only for few M\&As.

The various sampling allows us to look at whether the market makes a distinction in the type of deal. Firstly, the tests show a positive and statistically significant abnormal return for the target group. Thus, M\&As may be motivated by 
the desire to replace inefficient management and to improve X-efficiency. This result is consistent with the finding of Houston and Ryngaert [1994] and DeLong ([2001a], [2001b]) for American banks, and Cybo-Ottone and Murgia [2000] for European banks. Secondly, our results show that the market reacts positively to M\&As with geographic specialisation, suggesting that the market expects benefits such as reduced costs. Another interpretation of this result is that such M\&As could be expected to take advantage of market power. By focusing on a particular market, merging banks could take advantage of monopolistic or oligopolistic rents. Our finding is consistent with this of Delong ([2001a], [2001b]) and Cybo-Ottone and Murgia [2000].

Thirdly, the cross-products diversification deals capture positive expectations from the market. This result suggests that scope economies and/or a positive effect of the risk diversification are expected when a bank is engaged in multiple products activity. Note that these results are different from those obtained on American banks. Delong ([2001a], [2001b]) shows evidence that the market reacts negatively to the announcements of M\&As with activity diversification. However, we have to remember that the universal banking principle that characterizes Europe implies that there are no stringent limits to product market diversification from commercial banking into investment banking and insurance. The US legislation during the period under study has been more restrictive both on cross ownership and cross selling between banking and insurance or investment firms. In this respect, the US diversification cannot be compared to the European one. 
With the aim of explaining the probability of abnormal returns occurrence, we further explore our data set by crossing variables. Due to the number of combined variables, a Probit estimation is used.

\section{PROBIT ANALYSIS OF DEAL TYPE AND ABNORMAL RETURNS}

We examine the link between the occurrence of abnormal returns for bank $\mathrm{i}$ on the event window and some features of the M\&As. We estimate a standard Probit model:

$$
Y_{i}=\alpha+\sum_{j=1}^{J} \beta_{j} X_{j i}+\varepsilon_{i}
$$

where $\mathrm{Y}_{\mathrm{i}}$ is a binary variable that takes value 1 if the event (abnormal return) occurs or 0 if not and $\mathrm{X}_{\mathrm{ji}}$ is a characteristic feature of the transaction entered into by the bank i. Four binary explained variables are alternatively introduced according to: (1) the statistics $\mathrm{TP}_{1 \mathrm{i}}$ or $\mathrm{TNP}_{1 \mathrm{i}}$ (parametric or non-parametric) used to test the null; (2) the sign, positive or negative, of $\mathrm{CAR}_{\mathrm{i}}$ :

- $\mathrm{P}_{-} \mathrm{CAR} \_\mathrm{P}=1$ if the parametric test $\mathrm{TP}_{1 \mathrm{i}}$ establishes at least one positive and significant $\mathrm{CAR}_{\mathrm{i}}$ event window among the twelve defined above $\left(\mathrm{w}_{1}\right.$ to $\left.\mathrm{w}_{12}\right)$, and 0 otherwise,

. P_CAR_N $=1$ if the parametric test $\mathrm{TP}_{1 \mathrm{i}}$ establishes at least one negative and significant $\mathrm{CAR}_{\mathrm{i}}$ event window among the twelve,

. NP_CAR_P $=1$ if the non-parametric test $\mathrm{TNP}_{1 \mathrm{i}}$ establishes at least one positive and significant $\mathrm{CAR}_{\mathrm{i}}$ event window among the twelve,

. $\mathrm{NP} \_\mathrm{CAR} \_\mathrm{N}=1$ if the non-parametric test $\mathrm{TNP}_{1 \mathrm{i}}$ establishes at least one negative and significant $\mathrm{CAR}_{\mathrm{i}}$ event window among the twelve. 
The standard Probit model is estimated with a set of explanatory variables that handle with the previous characteristics of the M\&As:

$1 /$ The status of the entity: BID $=1$ if the bank is a bidder, 0 otherwise; TAR $=1$ if the bank is a target, 0 otherwise,

2/ The geographical dimension: GEOD $=1$ if M\&As involve a geographical diversification, 0 otherwise; GEOF $=1$ if M\&As imply a geographic focus, 0 otherwise,

3/ Specialisation or the cross-products diversification: SPEC $=1$ if the operation involves an activity focusing, 0 otherwise; DIV $=1$ if the operation involves a crossproducts diversification, 0 otherwise,

and on an extended set of potentially explanatory variables:

4/ If M\&As involves cross product diversifying, it may be useful to state precisely the non banking operator's activity: INS $=1$ if the operation concerns a bank and an insurance service, 0 otherwise; $\mathrm{SEC}=1$ if the operation concerns a bank and a securities firm, 0 otherwise,

5/ Composite dummies are built on the basis of the previous variables: the product DIV*GEOF allows for the specific influence of diversifying activities with geographic focusing on positive or negative $\mathrm{CAR}_{i}$ probability; in such a manner, a lot of composite dummies which cannot be listed here are constructed and added to the set of explanatory variables ${ }^{11}$,

6/ The size control variable (SIZE) is defined as the ratio of market capitalisation of security $i$ to the global market capitalisation at the event date.

7/ Dummy variables are introduced to look for the presence of country effects. 
The optimal subset of explanatory variables in Table 3 is selected through a standard stepwise procedure: after selecting a first explaining variable, the other ones are progressively introduced in the ajustment on the basis of a maximum t-stat criterium. Then, if the introduction of this additional variable induces the non significativity (at 5\% traditionnal level) of an already present variable, this one is expelled from the ajustment. Significant variables are linked to the probability of having a positive or a negative abnormal return. These results complement those previously obtained in Table 2.

Firstly, our finding suggests that positive $\mathrm{CAR}_{\mathrm{i}}$ probability increases if bank i is a target. This result is consistent with the tests of Table 2 which show that a large share of our target sample presents a positive and significant abnormal return.

Secondly, we were expecting a positive and significant coefficient for the deals with cross-product diversification and geographic specialisation. In fact, we find on average a positive abnormal return for these ones (see Table 2). The Probit estimation shows that the combination of activity diversification and geographic specialisation decreases the probability of having a negative abnormal return. Thus, this conjunction may reduce the probability to destroy value.

Thirdly, we find also that the combination of the two criteria «target» and «geographic focusing» decreases the probability of having a negative abnormal return.

Fourthly, according to the "too-big-to-fail" (TBTF) argument, governments would decide that major banks are so vital they are not allowed to fail. If this argument is true, these banks would have an incentive to increase their riskiness so as to take advantage of higher expected returns; therefore, the larger the institution, the higher should be the abnormal return upon the merger announcement. Our finding 
doesn't support the TBTF argument: the probability of having a positive abnormal return decreases with the size of the bank. This result is consistent with that of DeLong ([2001a], [2001b]). Fifthly, there are no country effects. The set of country dummies is not significant.

\section{SUMMARY AND CONCLUSIONS}

This study examines stock market reactions in terms of changes in expected returns to bank M\&As that have been announced from 1991 to 2001 in 13 European countries. A Bivariate GARCH model, which relies on the joint density of individual and market returns, is used to construct abnormal returns. M\&As were divided into several groups depending upon activity and geographic specialisation or diversification.

Our results show that there is, on average, a positive and significant increase in value for target banks. Moreover, we find that the market distinguishes among various types of M\&As. On average there is a positive and significant market reaction for the two following type of transactions: cross-product diversification and geographic specialisation. On the contrary, M\&As with focused activity and geographic diversification did not gain a positive market's expectation. A Probit estimation is used to further explore our dataset by crossing the criteria of M\&As classification. From this we find that the combination of activity diversification and geographic specialisation decreases the probability of having a negative abnormal return. 


\section{AKNOWLEDGEMENTS}

We would like to thank Andy Mullineux (University of Birmingham) and Amine Tarazi (University of Limoges) for their helpful comments.

\section{REFERENCES}

Bos, T and Newbold, P. (1984) An empirical investigation of the possibility of systematic stochastic risk in the market model, Journal of Business, 57, 35-41.

Cybo-Ottone, A. and Murgia, M. (2000) Mergers and shareholder wealth in European banking, Journal of Banking and Finance, 24, 831-859.

DeLong, G.L. (2001a) Stockolder gains from focusing versus diversifying bank mergers, Journal of Financial Economics, 59, 221-252.

DeLong, G.L. (2001b) Focusing versus diversifying bank mergers: analysis of market reaction and long term performance, WP Department of Economic and Finance, City University of New-York, Baruch College, January.

Fabozzi, F.J. and Francis, J.C. (1978) Beta as a random coefficient, Journal Financial and Quantitative Analysis, 13, 101-115.

Frame, W.S. and Lastrapes, W.D (1998) Abnormal return in the acquisition market : the case of bank holding companies, 1990-1993, Journal of Financial Services Research, 14.2, 145-163.

Hannan, T.H. and Wolken, J.D. (1989) Returns to bidders and targets in the acquisitions process: evidence from the banking industry, Journal of Financial Services Research, 3, 5-16.

Houston, J.F. and Ryngaert, M.D. (1994) The overall gains from large bank mergers, Journal of Banking and Finance, 18, 1155-1176. 
Pilloff, S.J. and Santomero, A.M. (1998) The value effects of bank mergers and acquisitions, in Aminhud, Y. and Miller, G. (Eds), Bank mergers and acquisitions, Kluwer Academic Publishers, Boston, 59-78. 
1. This figure represents complete M\&As with majority interests.

2. An event study is an analysis of whether there was a statistically significant reaction in financial markets to past occurrences of a given type of event that is hypothesised to affect public firms' market values.

3. For example, the deal between General de Banque SA (Belgium commercial bank) and Fortis AG (Belgium insurance company) in 1998 is classified as a M\&A with cross-product diversification and geographic specialisation. On the contrary, the deal between Dresdner Bank (German commercial bank) and Kleinwort Benson Iberfomento (Spanish commercial bank) in 1998 is classified as a M\&A with geographic diversification and activity specialisation.

4. See «Mergers and Acquisitions»- European Economy - Supplement A, Economic trends, $n^{\circ} 5 / 6-2000$.

5. BIS, « Report on Consolidation in the financial sector », January 2001.

6. The SDC-M\&A database is based on an American classification of companies in all branches of industry (Standard Industrial Classification (SIC)) and obeys to the US regulation requirements. SDC-M\&A partitions the financial sector into three industries: the banking industry (banking), the insurance industry (insurance) and investment businesses and financial companies (securities and others). In order to homogenise our study, we selected the banking firms as they were reported by SDC that is, the general classification «Commercial Banks, Bank Holding Companies» and, more particularly, the following codification: code 6000 (Bank, non US-chartered) and code 6029 (Commercial Bank, net).

7. We considered in this group the transactions between a bank (code 6000 and 6029) and a securities firm or an insurance firm at the domestic level only.

8. Notice that $\mathrm{T}=\mathrm{D}-\mathrm{J}-1$.

9. For windows $\mathrm{w}_{1}$ to $\mathrm{w}_{4}$, we get : $\mathrm{M}=\mathrm{J}, \mathrm{U}=\mathrm{D}-1$; for $\mathrm{w}_{5}$ to $\mathrm{w}_{8}$, we get : $\mathrm{M}=\mathrm{J}+1$ and 
$\mathrm{U}=\mathrm{D}+\mathrm{J}$; for $\mathrm{w}_{9}$ to $\mathrm{w}_{12}$, we have $: \mathrm{M}=2 \mathrm{~J}+1$ and $\mathrm{U}=\mathrm{D}+\mathrm{J}$.

10. We carry out tests for all the windows defined above. In order to simplify the presentation, we present here the results for two windows. However, the results obtain for the windows $[-7,+7]$ and $[-15 .+15]$ are robust for all the other ones. Thus tests in Table 2 are representative for all the windows considered. Other tests are available from the authors.

11. TAR*INS for example, indicates a deal where the bank is a target and where the bidder is an insurance company. 
Table 1. M\&As deals by country

\begin{tabular}{|l|rrrr|r|}
\cline { 2 - 5 } \multicolumn{1}{c|}{} & DIV\&GEOF & SPEC\&GEOF & DIV\&GEOD & SPEC\&GEOD & \multicolumn{2}{c|}{ Total } \\
\hline Germany & 9 & 5 & 6 & 1 & 21 \\
Austria & 1 & 2 & 1 & 0 & 4 \\
belgium & 1 & 3 & 1 & 1 & 6 \\
Denmark & 1 & 0 & 1 & 0 & 2 \\
Spain & 2 & 4 & 1 & 0 & 7 \\
France & 17 & 9 & 7 & 1 & 34 \\
Greece & 0 & 4 & 0 & 0 & 4 \\
Ireland & 0 & 0 & 2 & 0 & 2 \\
Italy & 17 & 27 & 0 & 0 & 44 \\
Netherlands & 0 & 1 & 3 & 1 & 5 \\
Portugal & 1 & 3 & 2 & 0 & 6 \\
Switzreland & 6 & 8 & 4 & 0 & 18 \\
UK & 19 & 2 & 3 & 3 & 27 \\
\hline Total & 74 & 68 & 31 & 7 & 180 \\
\hline
\end{tabular}

Source: SDC - M\&A DIV = activity diversification; GEOF=geographic focusing; $S P E C=$ activity specialisation; $G E O D=$ geographic diversification.

Table 2. Significance of abnormal returns

\begin{tabular}{|c|c|c|c|c|c|c|}
\hline \multirow[t]{2}{*}{ Sample } & \multirow[t]{2}{*}{$\begin{array}{c}\text { Event } \\
\text { window }\end{array}$} & \multirow[t]{2}{*}{$\mathrm{T} 2$ value } & \multicolumn{2}{|c|}{$\begin{array}{c}\text { Number of significant } \\
\text { TP1 }\end{array}$} & \multicolumn{2}{|c|}{$\begin{array}{c}\text { Number of significant } \\
\text { TNP1 }\end{array}$} \\
\hline & & & Positive & Negative & Positive & Negative \\
\hline Full sample & {$[-7,+7]$} & $2.412 *$ & 13 & 2 & 12 & 3 \\
\hline $\mathrm{N}=180$ & {$[-15,+15]$} & $2.624 *$ & 9 & 2 & 7 & 3 \\
\hline Target & {$[-7,+7]$} & $1.995^{*}$ & 7 & 1 & 3 & 1 \\
\hline $\mathrm{N}=29$ & {$[-15,+15]$} & $1.973^{*}$ & 4 & 0 & 3 & 1 \\
\hline Bidder & {$[-7,+7]$} & 1.567 & 6 & 1 & 9 & 2 \\
\hline $\mathrm{N}=151$ & {$[-15,+15]$} & 1.887 & 5 & 2 & 4 & 2 \\
\hline Deals with geographic & {$[-7,+7]$} & 0.26 & 0 & 0 & 1 & 0 \\
\hline $\begin{array}{l}\text { diversification } \\
\mathrm{N}=38\end{array}$ & {$[-15,+15]$} & -0.374 & 0 & 0 & 1 & 0 \\
\hline Deals with geographic & {$[-7,+7]$} & $2.491 *$ & 13 & 2 & 11 & 3 \\
\hline $\begin{array}{c}\text { specialisation } \\
\mathrm{N}=142\end{array}$ & {$[-15,+15]$} & $3.067 *$ & 9 & 2 & 6 & 3 \\
\hline Deals with activity & {$[-7,+7]$} & $2.058 *$ & 6 & 0 & 7 & 0 \\
\hline $\begin{array}{c}\text { diversification } \\
\mathrm{N}=105\end{array}$ & {$[-15,+15]$} & $2.672 *$ & 6 & 0 & 4 & 0 \\
\hline Deals with activity & {$[-7,+7]$} & 1.423 & 7 & 2 & 5 & 3 \\
\hline $\begin{array}{c}\text { specialisation } \\
\mathrm{N}=75\end{array}$ & {$[-15,+15]$} & 1.225 & 3 & 2 & 3 & 3 \\
\hline
\end{tabular}

* significant at the $5 \%$ level 
Table 3. Explaining the probability of Cumulated Abnormal Return ${ }^{\text {a }}$

Parametric statistic based binary explained variable

\begin{tabular}{|c|c|c|c|c|c|}
\hline \multirow[t]{2}{*}{ Variable } & \multicolumn{2}{|c|}{$\begin{array}{c}\mathrm{P}\left(\text { obtain a positive } \mathrm{CAR}_{\mathrm{i}}\right) \\
\text { P_CAR_P }\end{array}$} & \multirow[t]{2}{*}{ Variable } & \multicolumn{2}{|c|}{$\begin{array}{c}\mathrm{P}\left(\text { obtain a negative } \mathrm{CAR}_{\mathrm{i}}\right) \\
\text { P_CAR_N }\end{array}$} \\
\hline & $\hat{\beta}^{\prime}$ & z-stat (Prob) & & $\hat{\beta}^{\prime}$ & Z-stat (Prob) \\
\hline TAR & 0.647 & $\begin{array}{l}2.490 * \\
(0.013)\end{array}$ & $\mathrm{DIV}^{*} \mathrm{GEOF}$ & -0.971 & $\begin{array}{c}-2.901 * * \\
(0.004)\end{array}$ \\
\hline
\end{tabular}

Non-parametric statistic based binary explained variable

\begin{tabular}{|c|c|c|c|c|c|}
\hline Variable & \multicolumn{2}{|c|}{$\begin{array}{c}\left.\text { P(obtain a positive } \mathrm{CAR}_{\mathrm{i}}\right) \\
\text { NP_CAR_P }\end{array}$} & Variable & \multicolumn{2}{|c|}{$\begin{array}{c}\mathrm{P}\left(\text { obtain a negative } \mathrm{CAR}_{\mathrm{i}}\right) \\
\text { NP_CAR_N }\end{array}$} \\
\hline \multirow[t]{2}{*}{ Variable } & \multicolumn{2}{|c|}{$\mathrm{P}\left(\right.$ obtain a positive $\left.\mathrm{CAR}_{\mathrm{i}}\right)$} & Variable & \multicolumn{2}{|c|}{$\mathrm{P}\left(\right.$ obtain a negative $\mathrm{CAR}_{\mathrm{i}}$} \\
\hline & $\hat{\beta}^{\prime}$ & z-stat (Prob) & & $\hat{\beta}^{\prime}$ & z-stat (Prob) \\
\hline \multirow[t]{2}{*}{ SIZE } & -0.135 & $-2.133 *$ & TAR * GEOF & -0.703 & $-2.061 *$ \\
\hline & & $(0.033)$ & & & $(0.039)$ \\
\hline
\end{tabular}

a: Potential explanatory variables are: TAR, GEOD, DIV, SIZE, ASS, SEC, DIV*GEOD ,SPEC*GEOF, $D I V^{*} G E O D, \quad S P E C * G E O F, \quad T A R^{*} G E O D, \quad T A R^{*} G E O F, \quad T A R^{*} D I V, \quad T A R^{*} S P E C, \quad T A R^{*} G E O F * D I V$, $T A R * G E O F * S P E C, T A R * G E O D * D I V, T A R * G E O D * S P E C, T A R * I N S, T A R * S E C$, and the country dummies The composite dummies with BID are not introduced because BID is not significant in the estimation with only the elementary variables.. * represents significance at the $5 \%$ level and $* *$ represents significance at the $1 \%$ level. 